\title{
THE IMPACT OF BUSINESS TRANSFORMATION ON THE PROVISION OF PRODUCTS AND SERVICES IN OPERATIONAL-LEVEL RETAIL BUSINESSES: CASE STUDY
}

\author{
Xolani Protus Simamane, ${ }^{1}$ Robert Walter Dumisani Zondo ${ }^{2}$
}

\begin{abstract}
The retail industry is arguably one of the most prosperous sectors in the global economy. It serves as an intermediary between producers and consumers. Given its significance in the everyday lives of people in communities, and its role in national economies, the industry operates under extensive competition driven by growth in Information Technology which has dramatically changed the consumption patterns and buying behavior of consumers today. This study investigates the impact of transformation on the provision of products and services in operational-level retail businesses of KwaZuluNatal (KZN). This is a case study and the South African Post Office (SAPO) in KwaZulu-Natal (KZN) participated in the study. Of the 101 branch managers of SAPO, 72 participated in the study, representing a 71 percent response rate. The sample frame was obtained from both the Human Capital and the Infrastructure Management departments of SAPO in KZN. Descriptive statistics and chi-square tests were used to analyze the two objectives. That is, to establish if the change brought about by business transformation activities improves the provision of products and services in retail businesses and thereby improves the financial performance. It also determines if retail businesses undergoing transformation inspire confidence amongst employees, and thereby achieving their financial goals. The findings revealed that business transformation has the ability to improve the provision of products and services of retail businesses. Continuous communication with regards to transformation inspires confidence among employees, thereby leading to productivity improvements and the achievement of the organizational goals. Productive employees contribute positively to the financial performance of the business. The original value of this study is its approach in uncovering strengths and weaknesses of business transformation in the operational-level retail businesses.
\end{abstract}

JEL Classification Numbers: L21, L25, L32; DOI: http://dx.doi.org/10.12955/cbup.v5.978

Key words: business transformation, employee motivation, financial performance; retail; products and services.

\section{Introduction}

The provision of superior customer services is an important strategic objective of all companies seeking to achieve and retain their competitive advantage (Weng, 2011). Hence, the improvements in service performance have become critical to survival within the retail industry (McGregor, 2009). The retail industry functions under extreme competition in a technologically dominated environment. For a business to adapt under these external conditions, it has to undergo internal changes to respond to the external changes. During this transition, financial performance drops, quality of the service rendered declines, customer volumes decrease, and employee morale is affected (Fisher, 2005). The inability of the business to adapt to change and make use of the latest information technology systems and equipment hinders it from rendering satisfactory products and services. This ultimately results in customer dissatisfaction. According to Wang (2006), customer dissatisfaction due to the lack of retail businesses providing desired products and services is one of the factors that lead to reduced repurchase intentions in customers. On the other hand, a business transformation process that is not well communicated with the employees causes uncertainty and confusion within the workforce and results in decreased employee morale and motivation. This practice impacts negatively on employee productivity. According to Higuera (2010), unmotivated employees develop a lack of interest in their work and performance suffers, resulting in lower productivity. As a result, the overall financial performance suffers. Hence, this study investigates the impact of transformation on the provision of products and services in operational-level retail businesses, thereby improving their financial performance in KZN. It will also examine the influence of transformation in employee motivation.

\section{Transformation in the Provision of Satisfactory Product and Services}

In the current competitive environment, the provision of superior customer services is an extremely important strategic aim for all companies seeking to achieve and retain their competitive advantage (Weng, 2011). Given the severity of modern day global economic challenges, the improvements in service performance have become critical to survival within the retail industry (McGregor, 2009). According to the Aberdeen Group (2012), the role and the impact of service businesses have transformed and continue to transform in organizations around the world. Service champions are

\footnotetext{
${ }^{1}$ Durban University of Technology, Faculty of Management Sciences, Durban xolani.simamane@ postoffice.co.za

${ }^{2}$ Durban University of Technology, Faculty of Management Sciences, Durban. E-mail: dumisaniz@dut.ac.za
} 
needed across the organization to deliver and exceed customer expectations in order to continue the privilege of an extended, profitable relationship with the customers. McGregor (2009) states that when the need for the provision of superior service performance is communicated as an important element of the company's vision, and one which is advocated by the leader as an important organizational goal, members of the organization are likely to pursue it with vigor. According to Liao and Chuang (2007), when transformation leaders succeed in implanting such visions, values and beliefs into their employees, such employees will feel far more motivated to produce high-level commitment, and make positive changes in their attitude towards their work. This intensifies the employees' efforts to improve overall service performance. Nadiri and Tümer (2009) indicate that superior service quality has become a major differentiator in producing customer satisfaction and successful quality management is recognized as the most powerful competitive weapon that many leading service organizations possess. The following section discusses the importance of retail transformation in rendering of products and services.

\section{Importance of Transformation in Rendering Products and Services}

Retailers spend a lot of money each year to design, build, and furnish their establishments. Extensive competition prompts them to employ the store environment as a source of differential advantage (Brüggen, Foubert and Glemler, 2011). Brüggen et al. (2011) add that McDonald's began redesigning its 30000 stores in a makeover of unprecedented scale to provide the stores with a contemporary, welcoming image. Kentucky Fried Chicken (KFC) also responded to a changing environment by transforming their stores. The model store was intended to provide the optimal dining experience for a KFC customer and had to include the hottest, freshest food served daily; unparalleled hospitality and service; exciting new products; consumer choice and a variety of menu items; and a clean and comfortable dining experience. The model store would also help to promote the financial performance such as sales growth; the increased average spends and improved profitability. Furthermore, Brüggen et al. (2011) state that, despite the pervasiveness of store transformation, research to date does not provide sufficient understanding of customer responses to store makeovers. However, most research has revealed that customer response is influenced by individual servicescape parameters such as color, lighting as well as store characteristics such as store design and ambience. The relevant literature only focuses exclusively on store response to the servicescape. However, a complete evaluation of the transformation impact on the store performance also requires an understanding of whether transformation brings more people into a store in the first place. Dagger and Danaher (2014) state that shopping is an everyday element in most people's lives because the in-store experience continues to have high relevance and retailers must keep their servicescape modern, fresh and in line with competitors. The look, feel and mood of a retail store or service environment are unique and constructed purposefully to contribute to the persona of the brand and ultimately its profitability. Simon, Gomez, McLaughlin and Wittink (2009) explain that, in a buying decision, the place where the product or service is purchased or consumed is often more influential than the product itself. Most retailers have created not just a retail store but a place that customers will love. Creating a place to satisfy a customer is critical to a company's success. Simon, et al. (2009) indicates that, the satisfied customers may be the most consequential of all economic assets. Indeed they may be proxies for all other economic assets combined. Companies that are unable to satisfy their customers can expect to lose their market share to rivals that are offering better products and services at lower prices.

\section{The Role of Transformation in inspiring Confidence among Employees}

Motivation is the psychological process that gives behavior a purpose and a direction, a predisposition to behave in a positive manner to achieve specific unmet needs (Mishra and Gupta, 2009). Thus, work motivation is a key mechanism for maximizing the use of human capital for organizational success (Kanfer, Chen \& Pritchard, 2008). Motivated employees are highly involved in their work; they take initiative and make extra effort to help their organizations achieve goals (Parfvonova, 2009). Hence, the self-determination theory of motivation (SDT) posits that the employee job performance and wellbeing depends on the satisfaction of employee needs for autonomy, competence and relatedness at work (Parfvonova, 2009). For management to be successful, managers need to be true leaders who can understand what motivates their team and enroll employee participation in a way that combines their personal needs with group goals (Sidikova, 2011). According to Thurlow, Helms and Mills (2009), employee motivation during change can be affected by fear of failing in new tasks or not being 
able to adapt to change. Researchers proved that employee motivation and their performance are closely linked (Sidikova, 2011). Mishra and Gupta (2009) state that the success of retail companies is reliant on a motivated workforce. Companies use a variety of job motivators to retain employees' motivation and satisfaction. The most important motivators used by retail stores are working conditions, skills development, recognition, role clarity, career growth and support from management. Vlad (2012) identifies human capital in all service sector organizations, like retailing, as one of the pillars of success. Proper personnel planning, recruitment, motivation and retention are crucial to maintaining operational smoothness and consistent service to customers. As the retail industry continues to mature, employee satisfaction and retention is likely to persist as a challenge. Therefore, adequate steps must be taken by the retail industry in terms of recruiting, training, retaining, motivating, and engaging employees for enhanced productivity (Mishra and Gupta, 2009). According to Kumar (2011), motivating the workforce is not just a means to get people to pursue the organization's goal. Rather, it is an attempt to get people to buy in and take ownership of the organization's need as well as their own. Strategies such as appreciation of achievements, individual attention, empowerment and providing opportunity for leadership roles can be a powerful means of motivating knowledge workers who are satisfied with their package. Mishra and Gupta (2009) outline that the work patterns of the retail industry require employees to put in long hours of work which generally cause fatigue and lower motivation of the employees. Huddleston and Good (1999) agree that the success of retail companies is dependent on a motivated workforce. Motivation is vital in the work environment as it influences work performance and productivity. This study is designed around the following questions.

- Does the change brought by business transformation activities improve the provision of products and services in the retail business and thereby improve their financial performance?

- Do the retail businesses undergoing transformation inspire confidence to employees, thereby achieving their financial goals?

\section{Methodology}

The target population for this study consists of 101 middle-level branch managers of SAPO in KZN. Of the 101 middle-level branch managers of SAPO, 72 participated in the study, representing a 71 percent response rate. Data was collected using structured questionnaires that had 8 questions. The sample frame was obtained from both the Human Capital and the Infrastructure Management departments of SAPO. Both the descriptive and chi-square analysis were used to test the study objectives. The data collected was analyzed using the Statistical Package for the Social Sciences (SPSS) version 22.0.

\section{Findings}

\section{Influence of Transformation on provision of Product and Services}

The following Table 1 presents results on the influence of transformation on the products and services in the business.

Table 1 provides high percentage response rates on the influence of transformation on the provision of products and services. The percentages range from 83.1 to 91.7 per cent on the influence of transformation to the rendering of services and 83.3 to 90.3 per cent on product offerings. The analysis is in line with the study objective that establishes if the changes brought by transformation improve the provision of products and services in retail businesses and thereby improve the financial performance.

\section{Employee motivation during the Transformation Process}

The following Table 2 presents results on the motivation of the workforce during the transformation process.

Findings on Table 2 show high percentage response rates on the influence of the transformation process to improve employee motivation. The percentages range from 83.3 to 93.1 . The analysis indicates businesses undergoing transformation inspire confidence amongst employees, thereby achieving their financial goals. The chi-square test per each variable was also done. Hence, Table 3 presents test results for determining whether the scoring patterns across the different statements were similar. 


\begin{tabular}{|c|c|c|c|c|}
\hline \multicolumn{2}{|l|}{$\begin{array}{l}\text { Items on the provision of products and } \\
\text { services }\end{array}$} & \multirow{2}{*}{$\begin{array}{l}\text { Yes } \\
90.3\end{array}$} & \multirow{2}{*}{$\begin{array}{c}\text { Unsure } \\
9.7\end{array}$} & \multirow{2}{*}{$\begin{array}{l}\text { No } \\
0.0\end{array}$} \\
\hline Transformation has the ability to improve the & Products & & & \\
\hline provision of products and services. & Services & 91.7 & 8.3 & 0.0 \\
\hline \multirow{2}{*}{$\begin{array}{l}\text { Upgraded facility has an impact on rendering } \\
\text { products and services. }\end{array}$} & Products & 87.5 & 9.7 & 2.8 \\
\hline & Services & 84.7 & 11.1 & 4.2 \\
\hline \multirow{2}{*}{$\begin{array}{l}\text { Transformation process has an influence on the } \\
\text { provision of products and services. }\end{array}$} & Products & 83.3 & 13.9 & 2.8 \\
\hline & Services & 84.7 & 13.9 & 1.4 \\
\hline \multirow{2}{*}{$\begin{array}{l}\text { If the provision of products and services is } \\
\text { communicated as an important element of the } \\
\text { company's vision, the employees will pursue it } \\
\text { with passion. }\end{array}$} & Products & 86.1 & 12.5 & 1.4 \\
\hline & Services & 83.1 & 15.5 & 1.4 \\
\hline
\end{tabular}

Table 2: Employee motivation during the transformation process

\begin{tabular}{|l|c|c|c|}
\hline The items on employee motivation during transformation & Agree & Uncertain & Disagree \\
\hline Transformation has the ability to inspire confidence amongst employees. & 83.3 & 9.7 & 7.0 \\
\hline $\begin{array}{l}\text { Motivation increases employee productivity in business undergoing } \\
\text { transformation. }\end{array}$ & 87.5 & 8.3 & 4.2 \\
\hline $\begin{array}{l}\text { Intrinsic rewards improve the employee morale and result in } \\
\text { productivity. }\end{array}$ & 93.1 & 4.2 & 2.7 \\
\hline Extrinsic rewards motivate the employees to improve productivity. & 87.5 & 5.6 & 6.9 \\
\hline Source: Authors & & \\
\hline
\end{tabular}

Table 3: Test statistics for employee motivation

\begin{tabular}{|l|c|c|c|c|}
\hline & $\begin{array}{c}\text { Transformation has } \\
\text { the ability to inspire } \\
\text { confidence amongst } \\
\text { employees }\end{array}$ & $\begin{array}{c}\text { Motivation increases } \\
\text { employee productivity in } \\
\text { business undergoing } \\
\text { transformation }\end{array}$ & $\begin{array}{c}\text { Intrinsic rewards } \\
\text { improve the } \\
\text { employee morale } \\
\text { and result in } \\
\text { productivity. }\end{array}$ & $\begin{array}{c}\text { Extrinsic rewards } \\
\text { motivate the } \\
\text { employees to improve } \\
\text { productivity. }\end{array}$ \\
\hline Chi-Square & $58.139^{\mathrm{a}}$ & $68.694^{\mathrm{a}}$ & $94.667^{\mathrm{a}}$ & $77.861^{\mathrm{a}}$ \\
\hline $\mathrm{df}$ & 4 & 4 & 4 & 4 \\
\hline Asymp. Sig. & 0.000 & 0.000 & 0.000 & 0.000 \\
\hline
\end{tabular}

The p-values for all the variables in Table 3 are less than 0.05 level of significance. This implies a significant relationship of the variables of the transformation process to employee motivation.

\section{Discussion}

Retailers must create a place that customers will love to be. Hence, the retail companies must build quality service information that will help to align them with the ever-changing environment and improve the provision of products and services. Whilst business transformation improves the provision of products and services, the process must not affect employees negatively. According to Mishra and Gupta (2009), motivation is the psychological process that gives behavior a purpose and direction, a predisposition to behave in a positive manner to achieve specific unmet needs. Work motivation is a key mechanism for maximising the use of human capital for organizational success (Kanfer, Chen and Pritchard, 2008). The success of a retail business is dependent on a motivated workforce. This is equally true in the business that is involved in the transformation process.

\section{Conclusion}

It is crucial for the retail sector to ensure an effective flow of the transformation process and the creation of retail business that will remain relevant and be profitable in the future. This highlights the importance of the retail businesses on continuously scanning the environment, thus determining the 
opportunities that the market is presenting and, at the same time, identifying the threats it might face. The external environment that pose threats to retail business are economic conditions, changing consumer consumption patterns, competition and the IT. These market forces compel the retail business to change their internal environment to respond to the external environment and to adapt to the change by appropriately transforming their businesses.

\section{References}

Aberdeen Group. (2012). Service excellence and the path to business transformation. Journal of analyst insight (online), 54(2): 34-37. Available www: http://www.arbedeen.com (Accessed 30 October 2013).

Brüggen, E. C., Foubert, B. and Glemler, D. (2011). Extreme makeover: short and long term effects of a remodelled servicescape. Journal of marketing, 75(2): 71-87.

Dagger. S. and Danaher, P. J. (2014). Comparing the effect of store remodelling on new and existing customers. Journal of marketing, 78(62): 62-80.

Fisher, E. A. 2005. Facing the challenges of outcome measurement: the role of transformation leadership. Administration in social work, 29(4)

Higuera, V. 2010. Loss due to unmotivated employees (online). Available: http://www.smallbusiness.chron.com/managing employees (Accessed 14 June 2014).

Huddleston, P. and Good, L. (1999). Job motivators in Russian and Polish retail. International journal of retail and distribution management, 27(9): 383-93.

Kanfer, R., Chen, G., and Pritchard, R. D. (2008). Work motivation: past, present and future (online). Available: http://www.psychology.gatetech.edu (Accessed 23 October 2014).

Kumar, S. (2011). Motivating employee: An exploratory study on knowledge workers. South Asian journal of management, 3(2): 18-27.

Liao, H and Chuang, A. (2007). Transforming service employees and climate: a multi-level multi-source examination of transformational leadership in building long-term service relationships. Journal of applied psychology, 92(4): 1006-1019.

McGregor, J. (2009). When service means survival (online) .Available: http:// www.businessweek.com/magazine/toc/09.../B4121customer_service (Accessed 12 August 2014).

Mishra, S. and Gupta, B. (2009). Work place motivators and employees satisfaction: Study of retail sector in India. The Indian journal of industrial relations, 44(3).

Nadiri, H. and Tümer M. (2009). Retail service quality and behavioral intentions

(online).Available:http://www.ekonomiemanagement.cz/download/...78d0/10_nadiri_tumer (Accessed 01 November 2013).

Parfvonova, N. (2009). Employee motivation, performance and well-being: the role of managerial support for autonomy, competence and relatedness needs: The University of Western Ontario, London.

Sidikova, M. (2011).The impact of change on employees' motivation. Doctor of philosophy, Turku University of Applied Sciences.

Simon, D. H., Gomez, M. I., McLaughlin, E. W. and Wittink, D. R. (2009). Employee attitudes, customer satisfaction, sales performance: assessing the linkages in US grocery store. Wiley InterScience, 30(2): 27-41.

Thurlow, A., Helms, J. and Mills, .S. (2009). Change talk and sense making. Journal of organizational change management, 22(3): 457-579.

Vlad, S. (2012). The motivation and ways of motivating the human resources: Best Western hotel central Arad. Annals of the university of Oradea, Economics science series, 21 (12):398-403.

Wang, B. 2006. Effects of dissatisfaction on customer repurchase ddecisions in e-commerce: an emotion based pperspective. Journal of electronic commerce research, 13(3): 224-237.

Weng, L. 2011. Superior service performance through transformational leadership. Asia Pacific management review, 16(2): 181-195. 